\title{
Genetic Distances of Three Mollusk Species Investigated by PCR Analysis
}

\author{
Hyun Oh, and ${ }^{\dagger}$ Jong-Man Yoon \\ Department of Aquatic Life Medicine, College of Ocean Science and Technology, Kunsan National University, \\ Gunsan 573-701, Republic of Korea
}

\begin{abstract}
Three species of Nortamea concinua (NC) and Haliotis discus hannai (HDH) from Tongyeong and Sulculus diversicolor supertexta (SDS) are widely distributed on the coast of the Yellow Sea, southern sea and Jeju Island in the Korean Peninsula under the innate ecosystem. There is a need to understand the genetic traits and composition of three mollusk species in order to evaluate exactly the patent genetic effect. PCR analysis was performed on DNA samples extracted from a total of 21 individuals using seven decamer oligonucleotides primers. Seven primers were shown to generate the unique shared loci to each species and shared loci by the three species which could be clearly scored. A hierarchical clustering tree was constructed using similarity matrices to generate a dendrogram, which was facilitated by the Systat version 10. 236 specific loci, with an average of 56.3 per primer, were identified in the NC species. 142 specific loci, with an average of 44.7 per primer, were identified in the HDH species. Especially, 126 numbers of shared loci by the three species, with an average of 18 per primer, were observed among the three species. Especially, the decamer primer BION-75 generated 7 unique loci to each species, which were identifying each species, in 700 bp NC species. Interestingly, the primer BION-50detected 42 shared loci by the three species, major and/or minor fragments of sizes $100 \mathrm{bp}$ and $150 \mathrm{bp}$, respectively, which were identical in all samples. As regards average bandsharing value (BS) results, individuals from HDH species (0.772) exhibited higher bandsharing values than did individuals from $\mathrm{NC}$ species (0.655). In this study, the dendrogram obtained by the seven decamer primers indicates three genetic clusters: cluster 1 (CONCINNA 01 CONCINNA 07), cluster 2 (HANNAI 08 HANNAI 14), cluster 3 (SUPERTEXTA 15 SUPERTEXTA 21). Comparatively, individuals of HDH species were fairly closely related to that of SDS species, as shown in the hierarchical dendrogram of genetic distances.
\end{abstract}

Key words : Genetic distance, Haliotis discus hannai, Hierarchical dendrogram, Jeju Island, Notoacmea concinna, Specific loci, Sulculus diversicolor supertexta, Tongyeong

\section{INTRODUCTION}

Notoacmea concinna (NC) is, belonging to class Gastroda, family Acmaeidae, widely distributed along the coasts of the southern sea and Jeju Island in the Korea under the natural ecosystem. They mainly dwell in the rocky areas of the tidal zone. They have dense radial ribs and triangular pyramid of shell in shape. This shellfish eat sessile diatoms and microscopic algae.

Sulculus diversicolor supertexta (SDS) is, belonging to class Gastroda, family Haliotidae, widely distributed along the coasts of Jeju Island of Korea and the several sea areas in Japan. They mainly inhabit in the rocky shores of the low tidal zone to approximately $15 \mathrm{~m}$ in depth. This shell

\footnotetext{
Manuscript received 6 January 2014, Received in revised form 25 January 2014, Accepted 7 February 2014

Corresponding Author: Jong-Man Yoon, Department of Aquatic Life Medicine, College of Ocean Science and Technology, Kunsan National University, Gunsan 573-701, Korea. Tel. : +82-63-469-1887, Fax : +82-63-463-9493, E-mail : jmyoon@ kunsan.ac.kr

This is an Open Access article distributed under the terms of the Creative Commons Attribution Non-Commercial License (http:// creativecommons.org/licenses/by-nc/3.0) which permits unrestricted non-commercial use, distribution, and reproduction in any medium, provided the original work is properly cited.
} 
fish are reddish-brown in shell color with ridges and growth rings on shell surface. They also have green-brown stripes on dorsal surface of soft body and greenish-purple on pedal sole. They have 7-9 respiratory pores with flowing water in contrast to other abalones. Their larvae eat sessile diatoms, microscopic algae and some debris (Min, 2001).

Haliotis discus hannai (HDH) is, belonging to class Gastroda, family Haliotidae, widely distributed along the coasts of the Yellow Sea, southern sea and Jeju Island in the Korean Peninsula and the several sea areas in China and Japan under the natural ecosystem. Abalone mainly dwells in the rocky shores of the open sea with brown algae from the low tidal zone to approximately $20 \mathrm{~m}$ in depth. This shell fish are reddish-brown in shell color with ridges and growth rings on shell surface. They have also black and yellow stripes on dorsal surface of soft body and greenish-purple on pedal sole. Their sexual maturity is determined by the olive-green coloration of the ovary, and ivory-white of the testis. Adult abalone can eat green algae, Enteromorpha spp. and Ulva spp., brown algae, Undaria pinnatifida, Laminaria spp., Ecklonia cava, red algae, and others (Kafuku \& Ikenoue, 1983).

As a rule, there are marked differences of the size, color and shape in three mollusk species according to the environmental conditions of habitat such as feed and winterization period. There is a need to understand the genetic traits and composition of their molluskin order to evaluate exactly the patent genetic effect. Our authors perform clustering analyses to elucidate the genetic distances among three malacological species of Notoacmea concinna and Haliotis discus hannai from Tongyeong and Sulculus diversicolor supertexta from Jeju Island of the Korean peninsula. However, these kinds of Korean mollusk, which are recognized important biometrically (Kim \& Chung, 1985: Kim et al., 1994), geographically (Choe \& Kim, 1988), reproductively (Kim et al., 2012) as well as biochemically (Mahmoud et al., 2010) are not genetically studied or researched like other shellfishes.
Therefore, in the present study, genomic DNAs isolated from three mollusk species were analyzed by 7 oligonucleotides decamer primers in order to make out the genetic distances of the three species by investigating their genetic similarity and diversity.

\section{MATERIALS AND METHODS}

1. Specimen sampling, separation of gDNA, decamer primers and amplification reactions

Muscle tissues were collected separately from three mollusk species of Notoacmea concinna and Haliotis discus hannai from Tongyeong and Sulculus diversicolor supertexta from Jeju Island of the Korean peninsula, respectively, as shown in Fig. 1. PCR analysis was carried out on DNA samples extracted from a total of 21 individuals using seven decamer oligonucleotides primers. DNA extraction should be carried out according to the separation and extraction methods (Song \& Yoon, 2013). After several washings, lysis buffer I ( $155 \mathrm{mM} \mathrm{NH}_{4} \mathrm{Cl} ; 10 \mathrm{mM} \mathrm{KHCO}_{3}$; $1 \mathrm{mM}$ EDTA) was added to the samples, and the mixture tubes were gently inverted. Ice-cold $70 \%$ ethanol was added, and then the samples were centrifuged at 19,621 $\mathrm{g}$ for 5 minutes to extract the DNA from the lysates. The concentration of the extracted genomic DNA was measured by optical density at $260 \mathrm{~nm}$ by a spectrophotometer (Beckman Coulter, Buckinghamshire, UK). The DNA pellets were incubation-dried for $2 \mathrm{hrs}$, held at $-40^{\circ} \mathrm{C}$ until analysis and then dissolved in the TE buffer (10 mM Tris$\mathrm{HCl}, \mathrm{pH}$ 8.0; 1 mM EDTA).

Amplification products were separated by electrophoresis in 1.4\% agarose gels (Bioneer Corp., Daejeon, Korea) with TBE (0.09 M Tris, pH 8.5; 0.09 M borate; 2.5 mM EDTA), using 100 bp DNA ladder (Bioneer Corp., Daejeon, Korea) as DNA molecular weight marker and detected by staining with ethidium bromide. Seven primers, BION-55 (5'GTCACGGACG-3'), BION-50 (5'-CAAGCGAGGA-3'), 


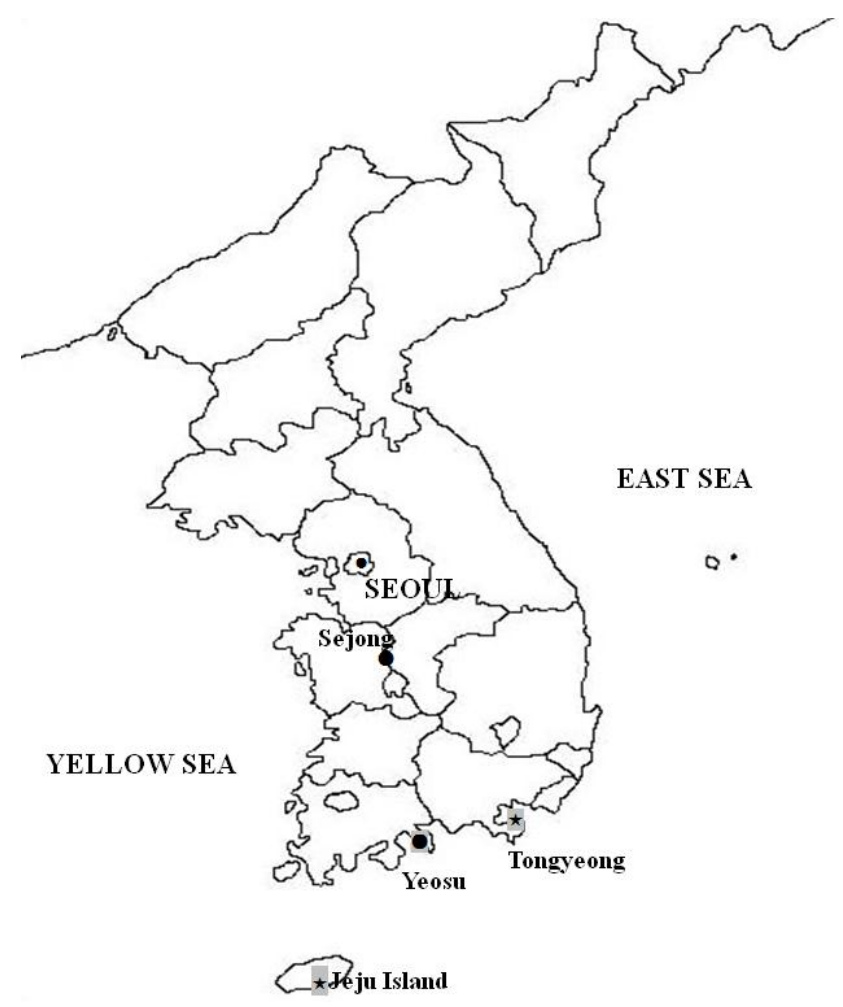

Fig. 1. Genomic DNA samples isolated from Notoacmea concinna, Haliotis discus hannai in Tongyeong ( $\star$ ), and Sulculus diversicolor supertexta in Jeju Island ( $\star$ ) off the southern sea of the Korean Peninsula.

BION-75 (5'-GAGGTCCACA-3'), BION-35 (5'-AGCG GCTAGG-3'), BION-61 (5'-GACCGCTTGT-3'), BION69 (5'-GCATCCACCA-3') and BION-66 (5'-TGGTGG ACCA-3') were shown to generate the unique shared loci to each species and shared loci by the three species which could be clearly scored. PCR was performed using Programmable DNA Thermal Cycler (MJ Research Inc., Waltham, MA, USA). Similarity matrix including bandsharing values (BS) between different individuals in the three mollusk species was generated according formula of Jeffreys \& Morton (1987), Yoke-Kqueen \& Radu (2006) and Yoon \& Kim (2004). A hierarchical clustering tree was constructed using similarity matrices to generate a dendrogram, which was facilitated by the Systat version 10 (SPSS Inc., Chicago, IL, USA).

\section{RESULTS AND DISCUSSION}

Genomic DNAs isolated from three mollusk species obtained in Tongyeong and Jeju Island, were amplified at several times by PCR reactions. The amplified products were separated by agarose gel electrophoresis (AGE) with oligonucleotide decamer primers and stained by ethidium bromide. The complication of the banding patterns was diverse spectacularly between the primers and two localities, as shown in Fig. 2. Based on the average bandsharing values of all samples, the similarity matrix ranged from 0.597 to 0.879 in the NC species, from 0.648 to 0.907 in the SDS species and from 0.694 to 0.884 in the $\mathrm{HDH}$ species, as illustrated in Table 1. The bandsharing value between individuals no. 08 and no. 09 was 0.907 , which was the highest value identified within the SDS species. Accordingly, in this study, the size of the DNA fragments varied wildly, from 100 to $1,600 \mathrm{bp}$. 236 specific loci, with an average of 56.3 per primer, were identified in the NC species. 142 specific loci, with an average of 44.7 per primer, were identified in the SDS species, as illustrated in Table 2. Many researchers studied the sizes of DNA fragments in the PCR profiles of five species of Eastern Pacific abalone (genus Haliotis) (Muchmore et al., 1998), blacklip abalone (Haliotis rubra) (Huang et al., 2000), the brittle star (Amphiura filiformis) (McCormack et al., 2000), turtle leg (Pollicipes mitella) (Song \& Yoon, 2013) and marsh clams (Corbicula spp.) (Yoon \& Kim, 2003). Especially, 126 numbers of shared loci by the three species, with an average of 18 per primer, were observed among the three species, as illustrated in Table 3. The decamer primer BION-50 generated 49 unique loci to each species in the HDH species. Especially, the decamer primer BION-75 generated 7 unique loci to each species, which were identifying each species in the SDS species. Interestingly, the primer BION-50 detected 42 shared loci by the three species, major and/or minor fragments of sizes, which were identical in all samples. As regards average bandsharing value (BS) results, individuals from HDH species (0.829) exhibited higher bandsharing 


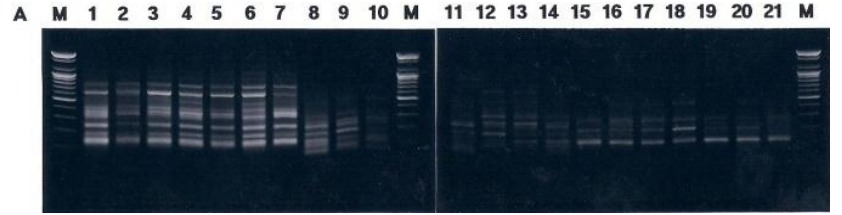

$\begin{array}{lllllllllllllllllllllllll}\text { B } & \text { M } & 1 & 2 & 3 & 4 & 5 & 6 & 7 & 8 & 9 & 10 & \text { M } & 11 & 12 & 13 & 14 & 15 & 16 & 17 & 18 & 19 & 20 & 21 & \text { M }\end{array}$

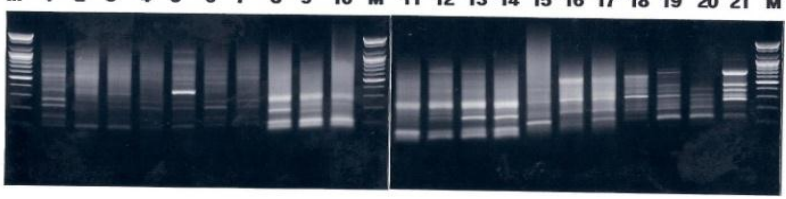

$\begin{array}{lllllllllllllllllllllllll}\text { C } & M & 1 & 2 & 3 & 4 & 5 & 6 & 7 & 8 & 9 & 10 & M & 11 & 12 & 13 & 14 & 15 & 16 & 17 & 18 & 19 & 20 & 21 & M\end{array}$

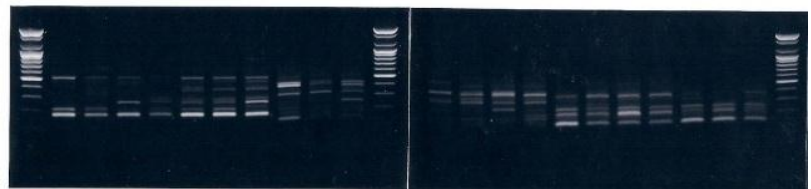

D $\begin{array}{lllllllllllllllllllllll}\text { M } & 1 & 2 & 3 & 4 & 5 & 6 & 7 & 8 & 9 & 10 & \text { M } & 11 & 12 & 13 & 14 & 15 & 16 & 17 & 18 & 19 & 20 & 21\end{array}$

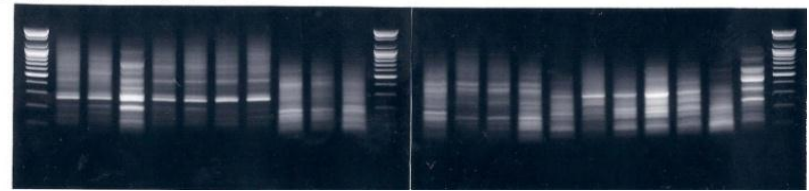

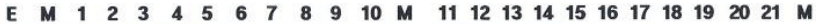

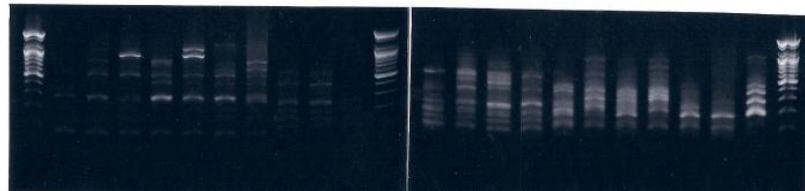

F $\begin{array}{llllllllllllllllllllllll}M & 1 & 2 & 3 & 4 & 5 & 6 & 7 & 8 & 9 & 10 & M & 11 & 12 & 13 & 14 & 15 & 16 & 17 & 18 & 19 & 20 & 21 & \text { M }\end{array}$

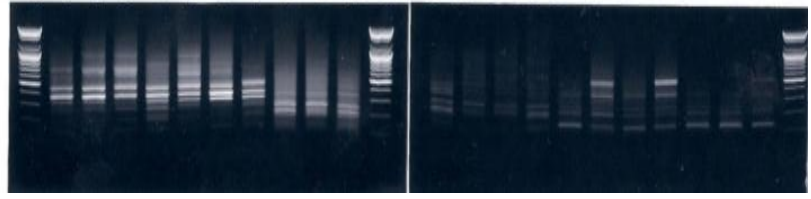

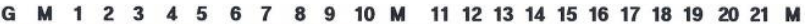

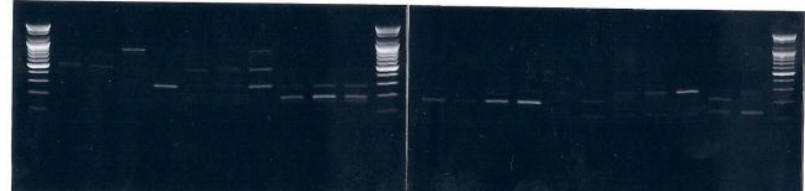

Fig. 2. PCR-based electrophoretic outlines of individuals acquired from three mollusk species. DNA isolated from Notoacmea concinna (lane 1 7), Sulculus diversicolor supertexta (lane 8 14) and Haliotis discus hannai (lane 15 21) were amplified by decamer primers BION-55 (A), BION-50 (B), BION-75 (C), BION-35 (D), BION-61 (E), BION-69 (F) and BION$66(\mathrm{G})$. The PCR products were separated by $1.4 \%$ agarose gel electrophoresis and detected by ethidium bromide staining. Each lane shows DNA samples extracted and purified from 21 individuals. $100 \mathrm{bp}$ ladder was used as a DNA molecular size marker (M). values than did individuals from NC species $(0.780)(P<$ 0.05), as illustrated in Table 4.

In this study, the dendrogram obtained by the seven decamer primers indicates three genetic clusters: cluster 1 (CONCINNA 01 CONCINNA 07), cluster 2 (SUPERTEXTA 08 SUPERTEXTA 14), cluster 3 (HANNAI 15 HANNAI 21), as shown in Fig. 3. The shortest genetic distance that displayed significant molecular differences was between individuals 08 and 09 from the SDS species (genetic distance $=0.041$, while the longest genetic distance among the twenty-one individuals that displayed significant molecular differences was between individuals NC no. 05 and HDH no. 21 (genetic distance $=0.627$ ). Comparatively, individuals of $\mathrm{HDH}$ species were fairly closely related to that of SDS species, as shown in the hierarchical dendrogram of genetic distances. PCR fragments discovered in this study may be useful as a DNA marker. In invertebrates, cluster analysis of the pairwise population matrix, generated from genetic data, showed that geographically close populations tended to cluster together in the blacklip abalone (Huang et al., 2000). The potential of oligonucleotides amplified polymorphic DNAs to identify diagnostic markers for species and population identification in shellfish (McCormack et al., 2000; Kim et al., 2004; Park et al., 2005; Song \& Yoon, 2013) has also been well established. Three mollusk species can be clearly distinguished by PCR-based approach. Therefore, this method can also be applied to other species of mollusk and make technicallyconvenient the analysis of many samples in a short time. In general, the species classification of three mollusk species is based on morphological variations in shell type, shell color, shell length, feet length and shell body weight (Chenyambuga et al., 2004). It is assumed that differences in such traits reflect distinct origins or genetic individuality (Chenyambuga et al., 2004). In future, additive researches should be in progress for more insightful species identifycation in Korean three mollusk species. 
Table 1. Similarity matrix including bandsharing values (BS) calculated using Nei and Li's index of the similarity of Notoacmea concinna (NC) and Haliotis discus hannai (SDS) from Tongyeong, and Sulculus diversicolor supertexta (HDH) from Jeju Island of Korean Peninsula, respectively

\begin{tabular}{|c|c|c|c|c|c|c|c|c|c|c|c|c|c|c|c|c|c|c|c|c|c|}
\hline & \multicolumn{7}{|c|}{ BS from $\mathrm{NC}$} & \multicolumn{7}{|c|}{ BS from SDS } & \multicolumn{7}{|c|}{ BS from $\mathrm{HDH}$} \\
\hline & 1 & 2 & 3 & 4 & 5 & 6 & 7 & 8 & 9 & 10 & 11 & 12 & 13 & 14 & 15 & 16 & 17 & 18 & 19 & 20 & 21 \\
\hline 1 & - & 0.667 & 0.621 & 0.664 & 0.609 & 0.603 & 0.597 & 0.391 & 0.436 & 0.435 & 0.419 & 0.432 & 0.416 & 0.416 & 0.442 & 0.442 & 0.490 & 0.440 & 0.453 & 0.433 & 0.373 \\
\hline 2 & & - & 0.658 & 0.674 & 0.659 & 0.638 & 0.603 & 0.414 & 0.435 & 0.474 & 0.412 & 0.454 & 0.424 & 0.421 & 0.427 & 0.465 & 0.401 & 0.406 & 0.426 & 0.321 & 0.378 \\
\hline 3 & & & - & 0.700 & 0.760 & 0.666 & 0.704 & 0.369 & 0.403 & 0.465 & 0.412 & 0.427 & 0.412 & 0.399 & 0.403 & 0.521 & 0.375 & 0.441 & 0.409 & 0.347 & 0.396 \\
\hline 4 & & & & - & 0.820 & 0.769 & 0.803 & 0.546 & 0.583 & 0.558 & 0.560 & 0.521 & 0.579 & 0.592 & 0.585 & 0.583 & 0.576 & 0.597 & 0.598 & 0.485 & 0.524 \\
\hline 5 & & & & & - & 0.878 & 0.879 & 0.573 & 0.582 & 0.570 & 0.574 & 0.548 & 0.574 & 0.528 & 0.531 & 0.480 & 0.515 & 0.532 & 0.570 & 0.426 & 0.516 \\
\hline 6 & & & & & & - & 0.860 & 0.588 & 0.586 & 0.573 & 0.560 & 0.523 & 0.573 & 0.554 & 0.549 & 0.515 & 0.559 & 0.561 & 0.574 & 0.462 & 0.477 \\
\hline 7 & & & & & & & - & 0.630 & 0.628 & 0.625 & 0.610 & 0.590 & 0.611 & 0.593 & 0.576 & 0.537 & 0.561 & 0.585 & 0.611 & 0.507 & 0.502 \\
\hline 8 & & & & & & & & - & 0.907 & 0.882 & 0.648 & 0.661 & 0.736 & 0.733 & 0.716 & 0.628 & 0.689 & 0.681 & 0.726 & 0.680 & 0.618 \\
\hline 9 & & & & & & & & & - & 0.838 & 0.659 & 0.649 & 0.717 & 0.755 & 0.738 & 0.554 & 0.678 & 0.669 & 0.719 & 0.713 & 0.597 \\
\hline 10 & & & & & & & & & & - & 0.682 & 0.678 & 0.697 & 0.738 & 0.716 & 0.602 & 0.682 & 0.674 & 0.714 & 0.676 & 0.643 \\
\hline 11 & & & & & & & & & & & - & 0.799 & 0.799 & 0.772 & 0.654 & 0.496 & 0.569 & 0.550 & 0.608 & 0.548 & 0.516 \\
\hline 12 & & & & & & & & & & & & - & 0.837 & 0.816 & 0.568 & 0.551 & 0.522 & 0.537 & 0.518 & 0.592 & 0.444 \\
\hline 13 & & & & & & & & & & & & & - & 0.864 & 0.653 & 0.613 & 0.656 & 0.618 & 0.636 & 0.576 & 0.594 \\
\hline 14 & & & & & & & & & & & & & & - & 0.689 & 0.553 & 0.648 & 0.623 & 0.710 & 0.634 & 0.613 \\
\hline 15 & & & & & & & & & & & & & & & - & 0.733 & 0.859 & 0.767 & 0.812 & 0.758 & 0.703 \\
\hline 16 & & & & & & & & & & & & & & & & - & 0.830 & 0.862 & 0.694 & 0.653 & 0.733 \\
\hline 17 & & & & & & & & & & & & & & & & & - & 0.884 & 0.780 & 0.720 & 0.822 \\
\hline 18 & & & & & & & & & & & & & & & & & & - & 0.785 & 0.696 & 0.841 \\
\hline 19 & & & & & & & & & & & & & & & & & & & - & 0.804 & 0.786 \\
\hline 20 & & & & & & & & & & & & & & & & & & & & - & 0.696 \\
\hline 21 & & & & & & & & & & & & & & & & & & & & & - \\
\hline
\end{tabular}

Bandsharing values of three species of mollusks from two regions are above the diagonal.

Table 2. The number of average loci per lane, specific loci by PCR analysis using 7 primers in Notoacmea concinna and Haliotis discus hannai in Tongyeong and Sulculus diversicolor supertexta in Jeju Island of Korea

\begin{tabular}{|c|c|c|c|c|c|c|}
\hline \multirow{2}{*}{$\begin{array}{c}\text { Item } \\
\text { Primer }\end{array}$} & \multicolumn{3}{|c|}{ No. of average loci per lane } & \multicolumn{3}{|c|}{ No. of specific loci } \\
\hline & $\mathrm{NC}$ & SDS & $\mathrm{HDH}$ & $\mathrm{NC}$ & SDS & $\mathrm{HDH}$ \\
\hline BION-55 & $9.86(69)$ & $7.71(54)$ & $5.42(38)$ & 27 & 12 & 10 \\
\hline $\mathrm{BION}-50$ & $11.14(78)$ & $8.71(61)$ & $10.29(72)$ & 60 & 19 & 23 \\
\hline BION-75 & $7.28(51)$ & $5.86(41)$ & $4.43(31)$ & 30 & 34 & 13 \\
\hline BION-35 & $10.57(74)$ & $8.71(61)$ & $8.14(57)$ & 53 & 16 & 31 \\
\hline BION-61 & $8.14(57)$ & $6.43(45)$ & $7(49)$ & 36 & 31 & 28 \\
\hline BION-69 & $7(49)$ & $4.71(33)$ & $5(35)$ & 21 & 19 & 14 \\
\hline BION-66 & $2.29(16)$ & $2.57(18)$ & $2.43(17)$ & 9 & 11 & 10 \\
\hline Total No. & $56.3(394)$ & $44.7(313)$ & $42.7(299)$ & 236 & 142 & 129 \\
\hline Average No. per primer & 56.3 & 44.7 & 42.7 & 33.7 & 20.3 & 18.4 \\
\hline
\end{tabular}

The total number of loci generated by 7 primer in Notoacmea concinna and Haliotis discus hannai obtained from Tongyeong, Sulculus diversicolor supertexta in Jeju Island is shown in parentheses.

NC: Notoacmea concinna, SDS: Sulculus diversicolor supertexta, HDH: Haliotis discus hannai 
Table 3. The number of unique loci to each species and number of shared loci by the three species generated by PCR analysis using 7 decamer primers in Notoacmea concinna (NC), Sulculus diversicolor supertexta (SDS) and Haliotis discus hannai (HDH) species, respectively

\begin{tabular}{ccccc}
\hline \hline Item & $\begin{array}{c}\text { No. of unique loci } \\
\text { to each species }\end{array}$ & & $\begin{array}{c}\text { No. of shared loci } \\
\text { by the three species }\end{array}$ \\
\cline { 2 - 3 } \cline { 5 - 5 } $\begin{array}{c}\text { Primer } \\
\text { I species }\end{array}$ & NC & SDS HDH & & $\begin{array}{c}\text { Three species } \\
\text { (7 individuals } \\
\text { per species) }\end{array}$ \\
\hline BION-55 & 42 & 42 & 28 & 42 \\
BION-50 & 28 & 42 & 49 & 42 \\
BION-75 & 21 & 7 & 21 & 0 \\
BION-35 & 21 & 35 & 28 & 21 \\
BION-61 & 21 & 14 & 21 & 0 \\
BION-69 & 28 & 14 & 21 & 21 \\
BION-66 & 7 & 7 & 7 & 0 \\
\hline Total no. & 168 & 161 & 175 & 126 \\
\hline Average no. & 24 & 23 & 25 & 18 \\
per primer & & & &
\end{tabular}

Table 4. Multiple assessments of average bandsharing values (mean \pm SD) among Korean malacological species from Notoacmea concinna (NC), Sulculus diversicolor supertexta (SDS) and Haliotis discus hannai (HDH) were generated according to the bandsharing values and similarity matrix

\begin{tabular}{cccc}
\hline \hline Species & NC & SDS & HDH \\
\hline NC & $0.780 \pm 0.153^{\mathrm{c}}$ & $0.510 \pm 0.081^{\mathrm{a}}$ & $0.487 \pm 0.076^{\mathrm{a}}$ \\
SDS & - & $0.817 \pm 0.128^{\mathrm{cd}}$ & $0.625 \pm 0.070^{\mathrm{b}}$ \\
HDH & - & - & $0.829 \pm 0.115^{\mathrm{d}}$ \\
\hline
\end{tabular}

${ }^{\mathrm{a}-\mathrm{d}}$ : Values with different superscript are significantly different $(P<0.05)$. Each value is a result of three different experiments.

\section{ACKNOWLEDGEMENTS}

The authors are grateful to the referees who assisted with detailed rectification. Particular thanks also go to our laboratory collaborators, for their support in mollusk sampling, DNA extraction/purification, gel electrophoresis, and their aids with PCR techniques.

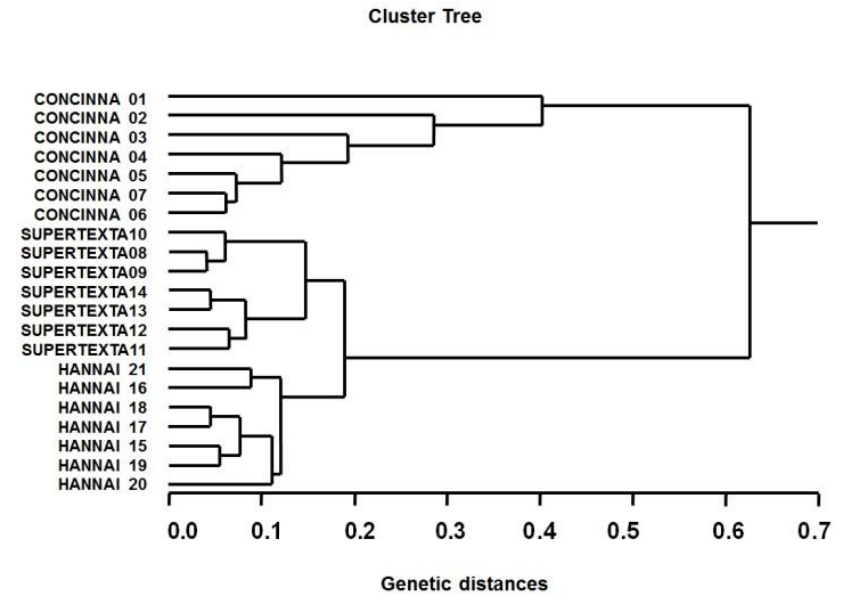

Fig. 3. Hierarchical dendrogram of genetic distances of individuals, obtained from three mollusk species of Korean Peninsula. The relatedness among differrent individuals in three malacological species of Notoacmea concinna (CONCINNA), Haliotis discus hannai (HANNAI) and Sulculus diversicolor supertexta (SUPERTEXTA) was generated according to the bandsharing values and similarity matrix.

\section{REFERENCES}

Chenyambuga SW, Hanotte O, Hirbo J, Watts PC, Kemp SJ, Kifaro GC, Gwakisa PS, Petersen PH, Rege JEO (2004) Genetic characterization of indigenous goats of sub-Saharan Africa using microsatellite DNA markers. Asian-Aust J Anim Sci 17:445-452.

Choe BL, Kim HS (1988) On the classification and distribution of archeogastropods from Korea waters. Korean J System Zool Special Issue 2:135-198.

Huang BX, Peakall R, Hanna PJ (2000) Analysis of genetic structure of blacklip abalone (Haliotis rubra) populations using RAPD, minisatellite and microsatellite markers. Mar Biol 136:207-216.

Jeffreys AJ, Morton DB (1987) DNA fingerprints of dogs and cats. Anim Genet 18:1-15.

Kafuku T, Ikenoue H (1983) Modern Methods of Aquaculture in Japan. Elsevier Scientific Publishing Company, pp. 172-182.

Kim JW, Chung SC (1985) On the growth of abalones, Sulculus 
diversicolor (Reeve) and S. diversicolor aquatilis (Reeve), in Cheju Island. Abstracts Mar Environ Res Instit 9:39-50.

Kim JY, Park CY, Yoon JM (2004) Genetic differences and DNA polymorphism in oyster (Crassostrea sp.) analysed by RAPD-PCR. Korean J Genet 26:123-134.

Kim CH, Yun SS, Kim YK, Byeon HS (1994) Studies on morphological variation of Archaeogastropoda (Patellacea) in Korea. Bull Sci Education 10:69-81.

Kim SH, Lee CH, Song YB, Kim BY, Sang YH, Lee YD (2012) Reproductive cycle of small abalone, Haliotis diversicolor aquatilis in Jeju Coastal Waters. Dev Reprod 16:145-153.

Mahmoud N, Dellali M, El Bour M, Aissa P, Mahmoudi E (2010) The use of Fulvia fragilis (Mollusca: Cardiidae) in the biomonitoring of Bizerta lagoon: A multimarkers approach. Ecological Indicators 10:696-701.

McCormack GC, Powell R, Keegan B (2000) Comparative analysis of two populations of the brittle star Amphiura filiformis (Echinodermata: Ophiuroidae) with different life history strategies using RAPD markers. Mar Biotechnol 2:100-106

Min DK (2001) Korea Mollusks with Color Illustration. Min shell house, pp. 44-47.
Muchmore ME, Moy GW, Swanson WJ, Vacquier VD (1998) Direct sequencing of genomic DNA for characterization of a satellite DNA in five species of Eastern Pacific abalone. Mol Mar Biol Biotechnol 7:1-6.

Park SY, Park JS, Yoon JM (2005) Genetic difference and variation in slipper lobster (Ibacus ciliatus) and deep sea lobster (Puerulus sewelli) throughout its distribution range determined by RAPD-PCR analysis. Korean J Genet 27:307-317.

Song YJ, Yoon JM (2013) Genetic differences of three Pollicipes mitella populations identified by PCR analysis. Dev Reprod 17:199-205.

Yoke-Kqueen C, Radu S (2006) Random amplified polymorphic DNA analysis of genetically modified organisms. J Biotechnol 127:161-166.

Yoon JM, Kim YH (2003) Wide marsh clam (Corbicula spp.) populations from three sites analysed by RAPDPCR-AGE. Bull Electrochem 19:337-348.

Yoon JM, Kim JY (2004) Genetic differences within and between populations of Korean catfish (S. asotus) and bullhead (P. fulvidraco) analysed by RAPD-PCR. AsianAustJ Anim Sci 17:1053-1061. 